\title{
Modeling a Formulation and Assessment of the Consumer Properties of the Special Purpose Starch Drink
}

\author{
Olga Mikhailovna Blinnikova ${ }^{1 *}$, Vadim Anatolyevich Babushkin ${ }^{1}$, Lyudmila Gennadievna Eliseeva ${ }^{2}$ and \\ Galina Severyanovna Usova ${ }^{3}$
}

${ }^{1}$ Department of Food Technology and Commodity Science, 393760, Michurinsk State Agrarian University, Internatsionalnaya St., 101, Russia; ${ }^{2}$ Department Science of Commodities and Commodity Examination Plekhanov Russian University of Economics, 117997, Moscow, Stremyanniy Lane, 36, Russia; ${ }^{3}$ Department of Biotechnology, Breeding and Seed Production of Agricultural Crops, Michurinsk State Agrarian University, Internatsionalnaya St., 101, Russia.

Abstract | Modeling of foodstuff suggest process of creation of the optimum recipes capable to provide the optimum level of adequacy of a complex of properties of foodstuff to the normalized sizes of contents macro and micronutrients, energy and requirements of the consumer. Using of a hydrolyzate of collagen as a component of the enriched foodstuff opens unlimited opportunities of production of the goods for functional, medical preventive and medical purposes, capable to fill the shortage of collagen and to stimulate the human body to produce its own protein. Drinking kissel is a perspective product type for enrichment the CCR (Central Chernosem Region's) fruit and berry's by collagen and natural physiologically active agents. At the same time the new types of drinking kissel useful to health, in assortment are which confirms the feasibility of updating the range due to enriched drinking kissels. Drinking of one glass of kissel covers the body daily need for ascorbic acid for $211.5 \%, \mathrm{P}$-active agents for $226.9 \%$, including catechins for $82.6 \%$, and for $200 \%$ in collagen. The benefit of the drink is due to simultaneous presence in the kissel of a high dose of data vitamins of natural origin. $\mathrm{P}$-active connections enhance biological effect of vitamin $\mathrm{C}$, and the high content of ascorbic acid in turn collagen. The designed fruit drinking kissel is the source of food fibers, macro and minerals.

Received | September 30, 2019; Accepted | July 15, 2020; Published | September 01, 2020

*Correspondence | Olga Mikhailovna Blinnikova, Department of Food Technology and commodity science, 393760, Michurinsk State Agrarian University, Internatsionalnaya st., 101; Email: mtrushin@mail.ru

Citation| Blinnikova, O.M., V.A. Babushkin, L.G. Eliseeva, G.S.Usova. 2020. Modeling a formulation and assessment of the consumer properties of the special purpose starch drink. Sarhad Journal of Agriculture, 36(3): 939-948.

DOI | http://dx.doi.org/10.17582/journal.sja/2020/36.3.939.948

Keywords | Modeling, Specialized food products, Starch drinks, Formulation, Nutritional value, Vitamins and vitamin-like compounds, Macroand microelements, Dietary fibers

\section{Introduction}

$\mathrm{T}$ he diet of a modern person includes various food products often with complex formulations, which determines the emergence and development of such areas as modeling, or development of multicomponent food products with the desired properties (Muratova et al., 2011; Blinnikova and Eliseeva, 2017; Blinnikova, 2017). In modeling them, developers aim at obtaining a product with high nutritional value using enrichers as additional ingredients.

Enrichment of food products consists in adding any essential nutrients and minor components to them, such as vitamins, macro and microelements, food fibers, polyunsaturated fatty acids, phospholipids, and other natural biologically active substances with the aim of preserving or improving the nutritional value of specific food products, or of the general diet for specific groups of the population. Another similar 
term is nitrification, which emphasizes the purpose of such enrichment-improving the nutritional value of the products. Abroad, this process is called fortification. These terms refer to the introduction of essential nutrients into the enriched food product (Bannikova and Ptichkina, 2012; Plaschina et al., 2002; Spirichev, 2000).

One of the ways of enriching food products is creating multicomponent food products with desired properties, which is aimed at the following:

- Restoring the normal levels of the nutrients lost during processing and storage

- Increasing the natural level of the nutrients content to satisfy the overall need in these nutrients in the minimum amount of consumed food

- Giving the products special characteristics by introducing functional and metabolic ingredients.

By their purpose, such products are classified into specialized, therapeutic, preventive, and functional ones.

Development of enriched food products for specialized and functional nutrition should become a solution to the problem of the intake of the nutrients needed for maintaining cellular immunity, the functioning of the digestive system, stable operation of the cardiovascular and the nervous systems, and the human organism as a whole. Due to the development of enriched rational food products with all nutrients necessary for the human organism properly combined, the relationship between two systems the organism and the environment is optimized (Doronin and Shenderov, 2002; Edelev et al., 2011; Kochetkova, 1995; Shatnyuk, 2005).

\section{Problem statement}

Diseases of joints today are among the most frequently diagnosed diseases. According to the statistics of the WHO (World Health Organization), joints diseases take third place in terms of occurrence rate, after diseases of the circulatory and the digestive systems. According to research studies, various joint damages occur in every fourth inhabitant of Russia, including the Central Federal District. Moreover, among people aged over 60, $97 \%$ complain of joint pain. Medical professionals say that joint diseases have become much "younger": Increasingly, these problems are manifested in the young people who spend most of their time in the office sitting at a computer for more than eight to ten hours a day without regular physical training. Excessive weight also affects the joints' ability to withstand loads.

This paper is dedicated to developing a specialized starch drink enriched with natural biologically active substances from the fruit and berry raw materials from the Central Chernozem region and collagen hydrolysate for preventing diseases of the locomotor system.

\section{Materials and Methods}

The objects of the research study were the ingredients used as formulation components for modeling the starch drink formulation: berries of honeysuckle of Zimorodok variety and Actinidia kolomikta of Soroka variety in conformance with the requirements of the Technical Regulations of the Customs Union 021/2011 "On food safety" (2011).

Honeysuckle of Zimorodok variety was obtained in the All-Russian Research Institute of Plant Production named after N.I. Vavilov, the author was L.P. Kuminov. The plant is medium-late ripening, frost-resistant, resistant to shedding. The average yield from the bush is $2.1 \mathrm{~kg}$. It is designated for dessert. The bush is weedy, compacted, with straight hairless shoots of green color. The berries are large $1.1 \mathrm{~g}$, round-oval with a thickened tip, juicy, dark blue, with blue bloom. The pubescence of berries is weak, simple. The skin of the fruit is thin. The taste is sweet, without aroma, refreshing, without bitterness, very good.

Actinidia of Soroka variety was obtained in the Moscow branch of VNIIR. The variety is mediumripening, relatively winter-hardy. The yield is $0.7 \mathrm{~kg}$ per bush. The average weight of the fruit is $3 \mathrm{~g}$. The shape of the fruit is elongated cylindrical. Peel is of medium thickness, green, with bright longitudinal stripes. The pulp is tender with strawberry aroma. The taste is sweet and sour. The variety is designated for universal usage.

Fresh berries of honeysuckle and actinidia were inspected for quality and rotten, pest-affected and immature berries were discarded; stalks and sepals were removed. The berries were washed with cold running water, crushed and triturated in pulping machines to obtain fruit mash with the particles of 0.8 $\mathrm{mm}$. The fruit mash was used to prepare kissel or was 
hot filled in bottles for further use in the preparation of kissel. As a result of different ripening periods of honeysuckle and actinidia berries, honeysuckle kissel was made of hot-bottled fruit mash, and actinidia kissel was prepared from fresh berries.

The chemical composition of the developed starch drink was studied using modern standard methods in accordance with the current regulatory documentation.

The vitamin value of the drink was determined by using the percentage of satisfying the need in vitamins, according to the physiological norms for the need in energy and nutrients (MP 2.3.1.2432-08, 2008).

Titratable acidity was determined according to GOST ISO 750-2013 "Products of fruit and vegetable processing. Determination of titratable acidity" using the titration method in the presence of a color indicator. For this, a sample prepared for analysis with a volume of $50 \mathrm{~cm}^{3}$ was pipetted into a beaker with a mechanical stirrer. A constantly shaken phenolphthalein solution was added to the beaker and titrated from the burette with a sodium hydroxide solution until the pink color appeared that did not disappear for $30 \mathrm{~s}$.

Titratable acidity T, mmol per $100 \mathrm{~cm}^{3}$ of product, taking into account dilution, was calculated using the formula:

$$
\mathrm{x} \mathrm{mg} / 100 \mathrm{~g}=20,4 \cdot \mathrm{E}
$$

Where;

$\mathrm{V}$ is the volume of the analyzed sample; $\mathrm{V}_{1}$ is the volume of the titrated sodium hydroxide solution spent on titration; $\mathrm{c}$ is the exact concentration of the titrated sodium hydroxide solution, $\mathrm{mol} / \mathrm{dm}^{3} ; \mathrm{V}_{0}$ is sample volume for analysis, $\mathrm{cm}^{3} ; 250$ is volumetric flask, $\mathrm{cm}^{3}$; 100 is coefficient for calculating titratable acidity per $100 \mathrm{~g}$ of product; 1000 is coefficient obtained in the calculation $250 / 25 \mathrm{~V}_{\mathrm{a}} \mathrm{c} 100 / \mathrm{V}_{0}$. Determining the level of acidity is necessary to establish the shelf life and compliance of the resulting product with the requirements of the standard.

The solids content in the analyzed kissel was determined by the refractometric method according to GOST ISO 2173-2013 "Products of fruit and vegetable processing. Refractometric method for the determination of soluble solids". For this purpose, the laboratory sample was thoroughly mixed and part of the sample was squeezed out through fourfold cheesecloth. The first drops were discarded and the remaining liquid was used for determination. The temperature of the analyzed solution was adjusted to the measurement temperature. Two-three drops were applied to a fixed prism of the refractometer and immediately covered with a movable prism. After lighting, a line was drawn dividing the dark and light field in the eyepiece, exactly at the crosshairs in the eyepiece window. Refractive index was determined. In accordance with the standard, the mass fraction of soluble solids was equal to the number found.

After conducting physical and chemical studies, organoleptic indicators and the proportion of impurities were determined in accordance with GOST 8756.1-2017 "Products of fruit, vegetable and mushroom processing. Methods for the determination of organoleptic characteristics, mass fraction of components, net mass or volume". The appearance, color, smell, texture and taste of kissel were assessed.

The vitamin value of the resulting product was determined according to GOST 24556-89 "Products of fruit and vegetable processing. Methods for determining vitamin C" using the titrimetric method, based on the extraction of vitamin $\mathrm{C}$ with hydrochloric acid followed by visual titration with a solution of sodium 2,6-dichlorophenolindophenolate until the light pink color is observed. To extract vitamin $\mathrm{C}$ from the analyzed product, a sample of $50 \mathrm{~g}$ was transferred to volumetric flasks with a capacity of $100 \mathrm{~cm}^{3}$. The walls of the flasks were washed with small portions of the extracting solution until the volume reached the mark. The contents were held for 10 minutes, stirred and filtered.

$5 \mathrm{~cm}^{3}$ of the obtained extract was pipetted into a flask with a capacity of $100 \mathrm{~cm}^{3}$, the volume was adjusted with water to $10 \mathrm{~cm}^{3}$ and titrated with a solution of sodium 2,6-dichlorophenolindophenolate until the faint pink color appeared that did not disappear for $20 \mathrm{~s}$.

At the same time, a control test was carried out for the content of reducing substances in the product. To do this, $5 \mathrm{~cm}^{3}$ of the extract was also placed in the flask; the same volume of acetate buffer solution was added. Formaldehyde solution in a volume equal to half the volume of the buffer solution was stirred and kept for $10 \mathrm{~min}$ in the flask previously closed with a stopper. Then the contents were titrated with a solution of 
2,6-dichlorophenolindophenolate sodium.

Mass fraction of ascorbic acid (X) in percent was calculated using the formula:

$$
\mathrm{x} \mathrm{mg} / 100 \mathrm{~g}=20,4 \cdot \mathrm{E}
$$

Where;

$\mathrm{V}_{1}$ is the volume of the solution of sodium 2,6-dichlorophenolindophenolate, spent on titration of the sample extract, $\mathrm{cm}^{3} ; \mathrm{V}_{2}$ is the volume of the solution of sodium 2,6-dichlorophenolindophenolate, spent on the control test, $\mathrm{cm}^{3} ; \mathrm{T}$ is the titer of sodium 2,6-dichlorophenolindophenolate solution, $\mathrm{g} / \mathrm{cm}^{3}$; $\mathrm{V}_{3}$ is the volume of extract obtained by extraction of vitamin $\mathrm{C}$ from a sample of the product, $\mathrm{cm}^{3} ; \mathrm{V}_{4}$ is the volume of extract used for titration, $\mathrm{cm}^{3} ; \mathrm{m}$ is the mass of the sample, $g$.

The arithmetic mean of the results of two parallel determinations is taken as the final test result.

The content of $\mathrm{P}$-active compounds anthocyanins, flavonols, and catechins was determined by the method of L.I. Vigorova and A. Ya. Tribune.

Preparation of the extract. Kissel in the amount of 5 $\mathrm{g}$ was mixed with $20 \mathrm{ml}$ of $50 \%$ ethanol, triturated with glass powder, transferred to a $100 \mathrm{ml}$ conical flask, heated in a water bath to the temperature of 60$70^{\circ} \mathrm{C}$ for 15 minutes, and filtered. The precipitate was again transferred to the flask, poured with alcohol and placed in a bath. The extraction was carried out 3-4 times, until the alcohol was completely discolored. The extract was collected in a $100 \mathrm{ml}$ volumetric flask and filled to the mark with ethyl alcohol. The extract was cooled for 30-40 minutes at a temperature of 0 ${ }^{\circ} \mathrm{C}$ and filtered.

Determination of flavonols. A solution obtained by mixing $2 \mathrm{ml}$ of extract and $4 \mathrm{ml}$ of $50 \%$ ethanol was used to balance the cuvettes.

A $2 \mathrm{ml}$ extract was poured into a dry tube, $2 \mathrm{ml}$ of $2 \%$ $\mathrm{AlCl}$ solution ( $2 \mathrm{~g}$ per $100 \mathrm{ml}$ of $50 \%$ ethyl alcohol) were added. After 2 minutes, $2 \mathrm{ml}$ of $10 \%$ sodium acetate solution ( $10 \mathrm{~g}$ per $100 \mathrm{ml}$ of $50 \%$ solution) were added. After 1 minute, the light absorption of the solution was determined on a KFK-2 photocolorimeter (10.05 $\mathrm{ml}$ cuvette, 400 light filter).

The calculation of the flavonols was carried out according to a calibration curve constructed according to the rutin:

$$
\mathrm{x} \mathrm{mg} / 100 \mathrm{~g}=20,4 \cdot \mathrm{E}
$$

Where;

$\mathrm{C}$ was the content of flavonols according to the calibration curve; B was the total volume of the extract $(100 \mathrm{ml}) ; 100$ was the conversion in \%; a was the sample $(5 \mathrm{~g})$; b was the volume of the extract taken for analysis $(2 \mathrm{ml}) ; 1,000$ was the transfer of mcg to $\mathrm{mg}$.

Determination of catechins. The analysis was based on the reaction of a vanillin solution with catechins of fruits and berries.

From the main alcoholic extract, $2 \mathrm{ml}$ of the extract were poured into 2 test tubes. $6 \mathrm{ml}$ of concentrated hydrochloric acid were added to the one test tube, and $6 \mathrm{ml}$ of vanillin solution $(0.25 \mathrm{~g}$ in $100 \mathrm{ml}$ of concentrated hydrochloric acid) were added to the other test tube.

The mixtures were stirred accurately for 3 minutes and determined at a wavelength of $540 \mathrm{~nm}$. A tube with concentrated hydrochloric acid served as a control.

The calculation was carried out according to a curve constructed by the tea catechin.

$$
\mathrm{x} \mathrm{mg} / 100 \mathrm{~g}=20,4 \cdot \mathrm{E}
$$

\section{Where;}

Cwas the catechin content according to the calibration curve; $\mathrm{B}$ was the total volume of the extract $(100 \mathrm{ml})$; 100 was the conversion in \%; a was the sample $(5 \mathrm{~g})$; $\mathrm{b}$ was the volume of the extract taken for analysis (2 $\mathrm{ml}) ; 1,000$ was the transfer of $\mathrm{mcg}$ to $\mathrm{mg}$.

Anthocyanins were determined by spectrophotometric method on a Genesys 10 uv spectrophotometer. 5 $\mathrm{ml}$ of the extract were poured into a test tube, 2.5 $\mathrm{ml}$ of acidic $96 \%$ ethanol $(20 \mathrm{ml}$ of concentrated hydrochloric acid $+80 \mathrm{ml}$ of $96 \%$ alcohol) were added to manifest anthocyanins. $75 \%$ ethyl alcohol served as a control. The wavelength was $535 \mathrm{~nm}$. The calculation was carried out according to the formula:

$$
\mathrm{x} \mathrm{mg} / 100 \mathrm{~g}=20,4 \cdot \mathrm{E}
$$

Where;

$\mathrm{E}$ was the optical density of the solution. 
The vitamin value of the drink was determined taking into account the percentage of satisfaction in them, according to the norms of physiological needs for energy and nutrients (MP 2.3.1.2432-08, 2008). The adjusted physiological need for vitamin $\mathrm{C}$ for adults was $90 \mathrm{mg} /$ day; for flavonoids $250 \mathrm{mg} /$ day, including for catechins $100 \mathrm{mg} /$ day. After determining the actual content of ascorbic acid and flavonoids (anthocyanins, flavonols and catechins) in the developed kissel, the percentage of the human body's satisfaction in these nutrients from the daily requirement for them when using one serving of a drink equal to $200 \mathrm{ml}$ was calculated. The calculation was carried out by proportions where the daily requirement for the nutrient was taken for $100 \%$ and the actual nutrient content was taken for $\mathrm{x}$ (MP 2.3.1.2432-08, 2008).

\section{Results and Discussion}

Creating specialized food products for preventive nutrition is at the interception of nutritional and biomedical science. The main objective of such products is resolving the problems of preventive and curative medicine. Consequently, the development of the formulation of the starch drink used for preventing diseases of the musculoskeletal apparatus is relevant, as the main consumers of these products are hospitals.

In addition to vitamin and mineral enrichment of food products, special attention has recently been given to protein preparations. This is due to the lack of dietary protein, which results in degeneration, decomposition of protein tissues, dysfunction of intestines, etc. One of the ways of removing protein deficiency in nutrition is the use of collagen hydrolysate in the production of commonly consumed food products, such as yogurt, starch drink, and other drinks, and confectionery.

By now, scientists from various countries have developed an easily digested form of natural collagen collagen hydrolysate, which acts as raw material in making preparations for oral nutritional supplements: for people with increased physical activity, athletes, the elderly, for prevention care of the musculoskeletal system; in the food industry in making oral nutritional supplements and specialized food products.

There is a broad list of oral nutritional supplements and medicinal products, where the active component is collagen hydrolysate; however, it is almost unused for making enriched food products. As for the market of the products enriched with collagen, they are currently represented only by few products.

The studies of the nutritive value of fruit and berry raw materials from the Central Chernozem zone performed by the authors showed that they were a valuable source of natural biologically active substances (Blinnikova et al., 2014; Eliseeva and Blinnikova, 2013a, 2013b). In addition, the balance of mineral substances in fruits and berries may be improved by enriching them with essential macro and micronutrients: $\mathrm{Mg}, \mathrm{Se}, \mathrm{I}_{2}, \mathrm{Zn}$, and $\mathrm{Mn}$, by the method of foliar treatment of the plants with aqueous solutions of the salts of sodium selenate $\left(\mathrm{Na}_{2} \mathrm{SeO}_{4}\right)$, potassium iodide $(\mathrm{KJ})$, zinc sulphate $\left(\mathrm{ZnSO}_{4}\right)$, manganese sulphate $\left(\mathrm{MnSO}_{4}\right)$, and magnesium sulfate $\left(\mathrm{MgSO}_{4}\right)$ during the vegetation period (Blinnikova and Eliseeva, 2015, 2016, 2017; Pat. 2533913 of the Russian Federation, 2014). The use of enriched fruit and berry raw materials in food production would expand the range of various groups of food products and give them functional properties. Quick freezing and low-temperature storage of fruit and berries would provide year-round use in food production. Collagen hydrolysate was used as the enriching additive.

In creating the offered category of products, the Norms of physiological needs in energy and nutrients for various groups of the Russian population were used, which are the scientific basis for nutrition planning in organized groups, and hospitals, and are used for substantiating the composition of specialized and enriched food products, etc.

Development of food products for prevention care of the musculoskeletal system involves the offered integrated approach for the use of the berries of edible honeysuckle and Actinidia kolomikta, which are the source of flavonoids, ascorbic acid, and other biologically active substances, and the enriching ingredient collagen hydrolysate.

Using the method of linear programming, the formulation of the starch drink made of Actinidia and honeysuckle was modeled with the maximum nutritional value and the following content of vitamins and other nutrients per $100 \mathrm{ml}$ of the drink: ascorbic acid not less than $45 \mathrm{mg}$, anthocyanins, and flavonols not less than $150 \mathrm{mg}$, catechins not less than $50 \mathrm{mg}$, dry substance not less than $12 \%$, organic acids 0.4 to 1.0 
$\%$, and proteins $5 \mathrm{~g}$. For setting the limits, the authors were guided by the requirements of GOST R 565582015 (2015) for fruit starch drinks, and the norms of the content of physiologically active substances in food products (MP 2.3.1.2432-08, 2008). With that, the content of collagen in a single serving of the product, i.e., $200 \mathrm{ml}$ of the drink, should be $200 \%$ of the daily need, which is $5 \mathrm{~g}$ (Matsumoto et al., 2006; Moskowitz, 2000). The content of dry matter in the ingredients of the starch drink formulation (FI) is shown in Table 1 , and its nutritional value in Table 2.

Table 1: Information matrix for developing the formulation of the starch drink from Actinidia and honeysuckle berries.

$\begin{array}{llll}\begin{array}{l}\text { Formulation ingre- } \\ \text { dients (FI) }\end{array} & \begin{array}{l}\text { Index, Possible range } \\ \mathbf{X}_{\mathbf{i}}\end{array} & \begin{array}{l}\text { Dry matter } \\ \text { of variation, \% }\end{array} & \begin{array}{l}\text { content, \% } \\ \text { Actinidia mash }\end{array} \\ \mathrm{x}_{1} & 10-15 & 14.2 \\ \text { honeysuckle mash } & \mathrm{x}_{2} & 10-15 & 12.0 \\ \text { sugar } & \mathrm{x}_{3} & 6.0-.5 & 99.85 \\ \begin{array}{l}\text { solution of the forti- } \\ \text { ficant }\end{array} & \mathrm{x}_{4} & 10.8 & 46.0 \\ \text { starch } & \mathrm{x}_{5} & 3.0-3.2 & 85.0 \\ \text { xanthan gum } & \mathrm{x}_{6} & 0.3 & 91.0 \\ \text { water } & \mathrm{x}_{7} & 49.8-60.9 & 0\end{array}$

The task was finding values $\mathrm{x}_{1}, \mathrm{x}_{2}, \mathrm{x}_{3}, \mathrm{x}_{4}, \mathrm{x}_{5}, \mathrm{x}_{6}, \mathrm{x}_{7}$, with which the target goal, i.e., the nutritional value of the developed starch drink, tended to the maximum:

$F(x)=18,295 x_{1}+19,306.23 x_{2}+99,850 \cdot x_{3}+46,000 \cdot x_{4}+$ $85,100 \cdot x_{5}+91,000 \cdot x_{6} \rightarrow \max (1)$

Based on the information matrix (Table 1), Table 3 shows a system of linear balance equations and limitations.
As a result of calculation, the following shares of the components in the starch drink formulation were obtained: $\mathrm{x}_{1}=0.117 ; \mathrm{x}_{2}=0.15 ; \mathrm{x}_{3}=0.065 ; \mathrm{x}_{4}=0.108$; $\mathrm{x}_{5}=0.032 ; \mathrm{x}_{6}=0.003 ;$ and $\mathrm{x}_{7}=0.525$. With that, $\mathrm{F}(\mathrm{x})$ $=21,947.958 \rightarrow \max$. In accordance with the obtained results, the formulation of the developed starch drink was made (Table 4).

The technological process of making starch drinks includes the following operations: Incoming inspection of raw materials, preparation of the components, mixing, thermal treatment, filling into the consumer containers; end product quality monitoring; labeling; packing into shipping containers; and transportation and storage.

The fresh honeysuckle and Actinidia berries were inspected for quality with rejection of the unripe berries and those affected by pests; the stalk and sepals were removed; the berries were washed in cold running water, crushed and mashed in mashing machines for obtaining the mash with particle size of $0.8 \mathrm{~mm}$, which was used for preparing the starch drink or hot-bottled for later use in the preparation of the drink. Due to various ripening periods of honeysuckle and Actinidia berries, mashed honeysuckle stored by hot bottling and fresh Actinidia mash were used in making the drink.

Collagen hydrolysate was introduced as a $46 \%$ aqueous solution. Starch was mixed with sugar and xanthan gum, and the mixture was introduced into one-third of cold water with continuous stirring. After that, the components were mixed in accordance with the formulation (except for collagen hydrolysate), the mixture was heated to $85^{\circ} \mathrm{C}$, then collagen hydrolysate solution heated to $97-98{ }^{\circ} \mathrm{C}$ was added, the finished product was hot-filled into previously prepared sterilized containers that were immediately closed.

Table 2: Nutritional value of formulation ingredients in the starch drink.

\section{The list of nutrients}

\section{ascorbic acid}

anthocyanins and flavonols

catechins

protein

carbohydrates

organic acids

Total
The amount of vitamins and other nutrients in the composition of formulation ingredients of the starch drink, $\mathrm{mg} / \mathbf{1 0 0} \mathrm{g}$

Actinidia honeysuckle

$1,255.5 \quad 32.23$

60.7

2,157

179.3

297

1,100

1,300

14,200

12,000

1,500

3,520

$18,295.5$

$19,306.23$

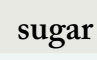

0

0

0

0

99,850

0

99,850 solution of the fortificant

0

0

0

46,000

0

0

46,000

$\begin{array}{ll}\text { starch } & \text { gum } \\ 0 & 0 \\ 0 & 0 \\ 0 & 0\end{array}$

100

$85,000 \quad 91,000$

$0 \quad 0$

$85,100 \quad 91,000$ 
Table 3: A system of balance linear equations and limitations.

\section{Balance}

Soluble dry substances

\section{Equations, limitations}

$\begin{array}{ll}\text { Ascorbic acid } & 85 \cdot x_{5}+91 \cdot x_{6} \geq 12 \\ \text { Anthocyanins and } & 1,255.5 \cdot x_{1}+32.23 \cdot x_{2} \geq 45 \\ \text { flavonols } & 60.7 \cdot x_{1}+2,157 \cdot x_{2} \geq 150 \\ \text { Catechins } & 179.3 \cdot x_{1}+297 \cdot x_{2} \geq 50 \\ \text { Protein } & 1,100 \cdot x_{1}+1,300 \cdot x_{2}+46,000 \cdot x_{4}+ \\ & 100 \cdot x_{5} \geq 5,000 \\ \text { Organic acids } & 1.0 \geq 1.5 \cdot x_{1}+3.52 \cdot x_{2} \geq 0.4 \\ \text { The lower limit } & \begin{array}{l}x_{1} \geq 0.10 ; x_{2} \geq 0.10 ; x_{3} \geq 0.06 ; x_{5} \geq 0.030 ; \\ x_{7} \geq 0.498\end{array} \\ \text { The upper limit } & x_{1} \leq 0.15 ; x_{2} \leq 0.15 ; x_{3} \leq 0.065 ; x_{5} \leq 0.032 ; \\ & x_{7} \leq 0.609 \\ \text { Collagen hydrolysate } & x_{4}=0.108 \\ \text { solution limitation } & \\ \text { Gum limitation } & x_{6}=0.003 \\ \text { Starch drink weight } & x_{1}+x_{2}+x_{3}+x_{4}+x_{5}+x_{6}+x_{7}=1\end{array}$

The system of linear balance equations was solved in Excel Solver.

Table 4: Starch drink formulation per 1,000 kg.

$\begin{array}{ll}\text { Raw material name } & \text { Formulation, kg } \\ \text { Actinidia fruit mash } & 117 \\ \text { Honeysuckle fruit mash } & 150 \\ \text { Sugar } & 65 \\ 46 \% \text { collagen hydrolysate solution } & 108 \\ \text { Starch } & 32 \\ \text { Xanthan gum } & 3 \\ \text { Water } & 525 \\ \text { Total } & 1000\end{array}$

The quality of the ready starch drink was assessed by a set of indicators.

The product was a homogeneous starch drink-like mass with a pleasant rich natural color characteristic of honeysuckle berries with harmonious sweet-sour flavor and delicate aroma. The physicochemical indicators of the starch drink quality met the requirements (Table 5).

The use of collagen hydrolysate in the starch drink formulation ensured high content of protein and amino acids in the product (Table 6).

Nutritional value of the starch drink is shown in Table 7.

Table 5: Physicochemical indicators of the starch drink quality.

Indicator name, unit of measurement

Mass fraction of soluble dry substances, $\%$

Mass fraction of fruits, $\%$

Mass fraction of titratable acids, $\%$

Vegetable impurities (stalks, not allowed etc.)

Impurities (not listed in the not allowed absent formulation)

Mass fraction of protein, \% unregulated $\quad 5.5 \pm 0.1$

Table 6: Amino acids content in the starch drink.
Indicator name, unit of measurement

Mass fraction of amino acids, \%

\section{Essential}

Valine

Leucine + Isoleucine

Lysine

Methionine

Cysteine

Threonine

Phenylalanine

Tyrosine

Nonessential

Alanine

Arginine

Aspartic acid

Histidine

Glycine

Glutamic acid

Proline

Oxyproline

Serine $0.059 \pm 0.001$

\section{Indicator value}

$0.143 \pm 0.003$

$0.239 \pm 0.002$

$0.045 \pm 0.001$

$0.051 \pm 0.001$

$0.107 \pm 0.003$

$0.087 \pm 0.002$

$0.038 \pm 0.001$
The use of mashed Actinidia and honeysuckle berries as fruit base characterized by the high content of biologically active substances allowed obtaining a product of high nutritional value, which was the source of ascorbic acid, anthocyanins, flavonols, catechins, pectin, fibers, and minerals. Figure 1 shows the data about the percentage of satisfying the human organism's daily need in individual nutrients per one serving of the product, i.e., $200 \mathrm{ml}$ of the starch drink.

Using one cup of starch drink covers the daily requirement for ascorbic acid by $211.5 \%$, for $\mathrm{P}$-active 
substances by $226.9 \%$, including catechins by $82.6 \%$.

Table 7: Nutritional value of the starch drink.

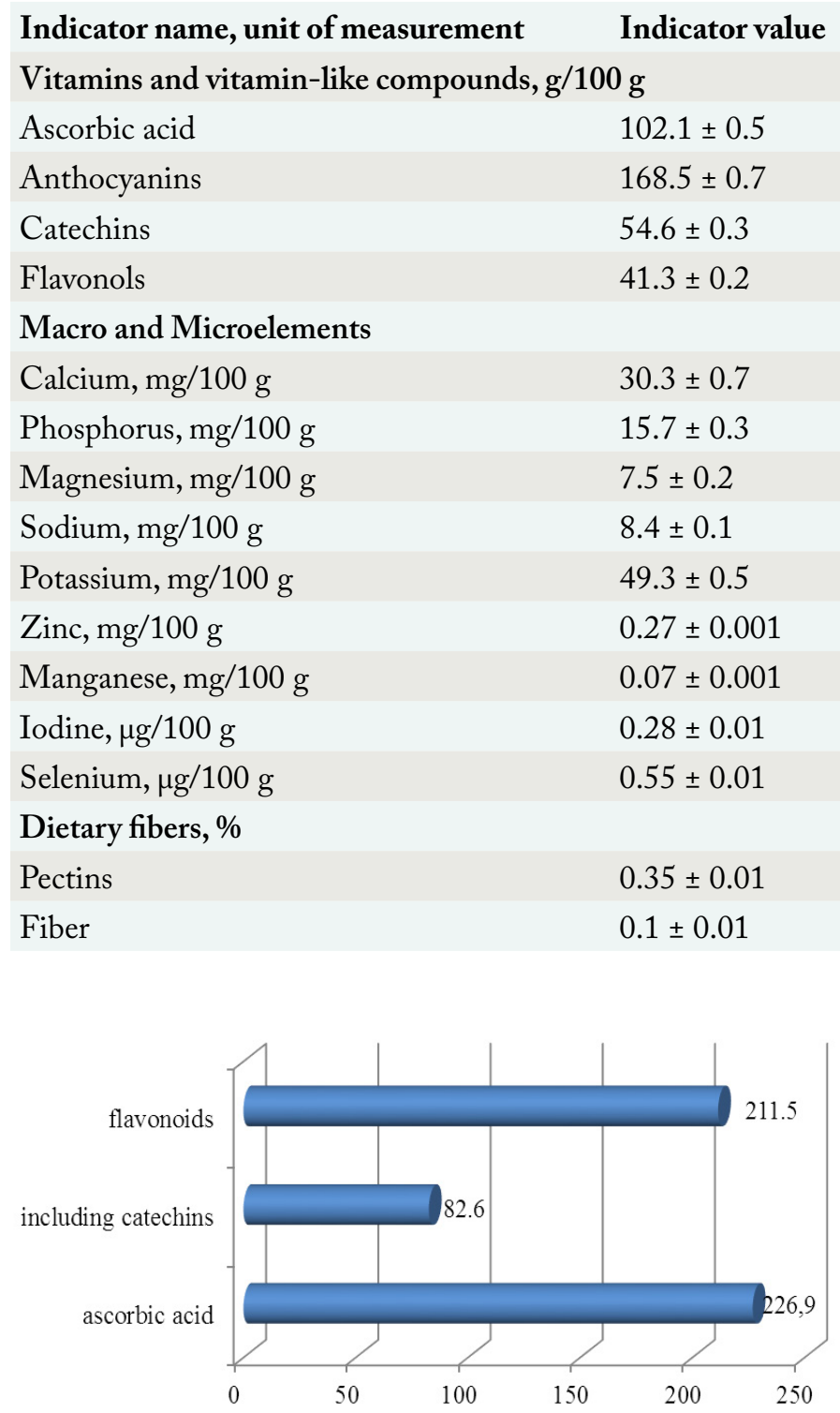

Figure 1: Satisfaction of the human organism's daily need in ascorbic acid and flavonoids, \%.

The developed fruit starch drink is a source of dietary fibers, and macro- and microelements. One serving of the starch drink provides $8.5 \%$ of manganese, $6 \%$ of calcium, $4.5 \%$ of zinc and dietary fiber, $3.9 \%$ of phosphorus and potassium, and $3.8 \%$ of magnesium to the human organism.

- In terms of safety and microbiological indicators, the starch drink meets the requirements of the Technical Regulations of the Customs Union TR CU 021/2011 On food products safety (Technical Regulations of the Customs Union 021/2011 “On food safety", 2011).

Thus, the use of linear programming method has allowed modeling the formulation of the starch drink for dietary preventive nutrition enriched with collagen, which has high nutritional value, required content of biologically active substances, and good organoleptic properties, and meets the requirements of normative documents (Pat. 2668338 of the Russian Federation, 2018). Technical documentation has been developed and approved for the developed fruit starch drink.

\section{Conclusions and Recommendations}

In modeling food products with the predetermined composition, approaches based on linear methods and experimental statistical programming are mainly used. In this research, in modeling the formulation of the starch drink for specialized nutrition, the method of linear programming was used. For the main raw material in modeling a starch drink formulation, Actinidia and honeysuckle berries have been used, which are unique natural concentrates of ascorbic acid and flavonoids, respectively, as well as a protein enriching ingredient, collagen hydrolysate.

The use of linear programming method has allowed modeling the formulation of the starch drink for dietary preventive nutrition enriched with collagen, which has high nutritional value, required content of biologically active substances, and good organoleptic properties, and meets the requirements of normative documents.

Drinking one cup of the starch drink covers the daily requirement for ascorbic acid by $211.5 \%$, for $\mathrm{P}$-active substances by $226.9 \%$, including catechins by $82.6 \%$, and collagen by $200 \%$. The advantage of the beverage is determined by the simultaneous presence of high dosages of these natural vitamins in the starch drink. $\mathrm{P}$-active compounds enhance the biological effect of vitamin $\mathrm{C}$, and the high content of ascorbic acid that of collagen. The developed fruit starch drink is a source of dietary fibers, and macro and microelements. One serving of the starch drink provides $8.5 \%$ of manganese, $6 \%$ of calcium, $4.5 \%$ of zinc and dietary fiber, $3.9 \%$ of phosphorus and potassium, and $3.8 \%$ of magnesium to the human organism.

\section{Novelty Statement}

A drinking kissel formulation has been developed for the prevention of diseases of the musculoskeletal system. The proposed integrated approach is associated 
with the use of honeysuckle and Actinidia kolomikta berries, which are a source of flavonoids, ascorbic acid and other biologically active substances, as well as an enriching ingredient collagen hydrolyzate.

\section{Author's Contribution}

OMB structuring the experimentaldesign,formulating the problem, collecting the data, literature review, organizing and conducting the statistical analysis, interpreting the results, writing a major portion of the paper, building the apparatus. VAB structuring the experimental design, formulating the problem. LGE and GSU structuring the experimental design, formulating the problem.

\section{Coflict of interest}

The authors have declared no conflict of interest.

\section{References}

Bannikova, A.V. and N.M. Ptichkina. 2012. Ispolzovanie polisakharidnykh dobavok $\mathrm{v}$ tekhnologii krakhmalosoderzhashchikh i sakharosoderzhashchikh produktov. Using polysaccharide additives in the technology of making starch-containing and sugar-containing products. Lap Lambert Academic Publishing, Saarbrücken.

Blinnikova, O.M., 2017.Proektirovanie retseptury i tovarovednaya otsenka fruktovogo napolnitelya dlya iogurta, obogashchennogo kollagenom. Development of a formulation and assessment of a collagen-enriched fruit filler for yogurts. In: The role of agricultural science in the development of agriculture of the Russian Federation: Materials of the International Scientific-Practical Conference dedicated to 105-th anniversary of the Voronezh State Agrarian University (November 2, 2017). Publishing House of the Voronezh State Agrarian University, Voronezh. pp. 241-246.

Blinnikova, O.M. and L.G. Eliseeva. 2015. Metodologiya obogashcheniya plodov i yagod iodom dlya obespecheniya ratsionalnogo pitaniya naseleniya. Methods of enriching fruits and berries with iodine for ensuring rational nutrition of the population. Food Ind. 9: 42-44.

Blinnikova, O.M. and L.G. Eliseeva. 2016. Obogashchenie yagod i plodov selenom i perspektivy ikh ispolzovaniya $\mathrm{V}$ profilakticheskom pitanii. Enriching berries and fruits with selenium and the perspectives of using them in preventive nutrition. Issues Nutr. 1: 85-91.

Blinnikova, O.M. and L.G. Eliseeva. 2017. Obogashchenie yagod magniem i perspektivy $\mathrm{ikh}$ ispolzovaniya $\mathrm{v}$ profilakticheskom pitanii. Enriching berries with magnesium and the perspectives of using them in preventive nutrition. Bull. Sci. Pract. 8(21): 70-78.

Blinnikova, O.M. and L.G. Eliseeva. 2017. Proektirovanie polikomponentnykh pishchevykh produktov s zadannymi svoistvami na osnove yagodnogo syrya Tsentralno-Chernozemnogo regiona. Developing multicomponent food products with desired properties based on berry raw materials from the Central Chernozem region. Technol. Food Proc. Ind. Agric. Healthy Food Prod. 5(19): 81-88.

Blinnikova, O.M., L.G. Eliseeva and E.Y. Koveshnikova.2014.Yagody aktinidii kolomikta - unikalnyi istochnik biologicheski aktivnykh veshchestv. Berries of actinidia kolomikta as a unique source of biologically active substances. Food Ind. 6: 19-21.

Doronin, A.F. and B.A. Shenderov. 2002. Funktsionalnoe pitanie. Functional nutrition Grant, Moscow.

Edelev, D.A., A.P. Nechaev and T.I. Demodova. 2011. Funktsionalnoe pitanie i perspektivnye tendentsii pishchevykh tekhnologii. In: Technologies and products for healthy nutrition. Functional food products: a collection of scientific works. FSBEI HPE Moscow State University of Food Production, Moscow. Funct. Nutr. Promising Food Technol. pp. 31-34.

Eliseeva, L.G. and O.M. Blinnikova. 2013a. Differentsirovanie perspektivnykh sortov plodovo-yagodnykh kultur po soderzhaniyu biologicheski aktivnykh soedinenii. Differentiation of promising varieties of fruit crops by the content of biologically active compounds. Food Ind. 6: 50-52.

Eliseeva, L.G. and O.M. Blinnikova. 2013b. Yagody zhimolosti syedobnoi bogatyi istochnik biologicheski aktivnykh veshchestv. Berries of edible honeysuckle as a rich source of biologically active substances. Storage Proc. Agric. Raw Mater. 7: 18-21.

GOST R 56558-2015. 2015. Canned food. Potable fruit kissels. General specifications. 
Standartinform, Moscow.

Kochetkova, A.A., 1995. Funktsionalnye produkty $\mathrm{v}$ kontseptsii funktsionalnogo pitaniya. Functional food products in the concept of functional nutrition. Food Ind. 2: 9-11.

Matsumoto, H., H. Ohara, K. Ito, Y. Nakamura and S. Takahashi. 2006. Clinical effects of fish type I collagen hydrolysate on skin properties. ITE Lett. 7(4): 386-390.

Moskowitz, R., 2000. Role of collagen hydrolysate in bone and joint disease. Semin. Arthritis Rheum. 30(2): 87-99. https://doi.org/10.1053/ sarh.2000.9622

MP 2.3.1.2432-08. 2008. Rational nutrition: norms of the physiological needs in energy and nutrients for different population groups in the Russian Federation.

Muratova E.I., S.G. Tolstykh, S.I. Dvoretsky, O.V. Zyuzina and D.V. Leonov. 2011. Avtomatizirovannoe proektirovanie slozhnykh mnogokomponentnykh produktov pitaniya. Automated design of complex multicomponent food products. Publishing house of FSBEI HPE TSTU, Tambov.

Pat. 2533913 of the Russian Federation. 2014. IPC C05D 5/00 C05D 9/02 A23L 1/304. The method of complex enrichment of fruits and berries with selenium, iodine, zinc, magnesium, and manganese.O.M.Blinnikova,L.G.Eliseeva; FSBEI HPE MichSAU. 2013119081/13: Application 24.04.2013; Published 27.11.2014, Bull. No. 33.7 pages.

Pat. 2668338 of the Russian Federation. 2018. IPC A23L 33/28 A23L 2/00 A23L 2/38 A23L 2/52 A23L A23L 29/212 29/281. Method of making enriched collagen starch drink for functional nutrition. O.M. Blinnikova, L.G. Eliseev; O.M. Blinnikova. 2017122545: Application 26.06.2017; Published 28.09.2018, Bull. No. 28.

Plaschina, I.G., M.A. Bulatov and D.M. Khaddad. 2002. Gummirabik: funktsionalnye svoistva i oblasti primeneniya. Gum arabic: Functional properties and areas of application. Food Ind. 6: 54-55.

Shatnyuk,L.N.,2005.Pishchevye mikroingredienty v sozdanii produktov zdorovogo pitaniya. Food microingredients in creating products for healthy nutrition. Food Ingredients. 2: 18-22.

Spirichev, V.B., 2000. Nauchnye printsipy obogashcheniya pishchevykh produktov mikronutrientami. Scientific principles of enriching food products with micronutrients. Issues Nutr. 4: 13-19.

Technical Regulations of the Customs Union 021/2011 “On food safety”. 2011. 